\title{
Immune evasion by Staphylococcus aureus conferred by iron-regulated surface determinant protein IsdH
}

\author{
Livia Visai, ${ }^{1,2}$ † Naoko Yanagisawa, ${ }^{3} \dagger$ Elisabet Josefsson, ${ }^{4}$ \\ Andrej Tarkowski, ${ }^{4} \ddagger$ Ilaria Pezzali, ${ }^{1}$ Suzan H. M. Rooijakkers, ${ }^{5}$ \\ Timothy J. Foster ${ }^{3}$ and Pietro Speziale ${ }^{1}$ \\ ${ }^{1}$ Department of Biochemistry, Viale Taramelli 3/b, 27100 Pavia, Italy \\ ${ }^{2}$ Center for Tissue Engineering, Via Ferrata 1, 27100 Pavia, Italy \\ ${ }^{3}$ Microbiology Department, Moyne Institute of Preventive Medicine, Trinity College, Dublin 2, Ireland \\ ${ }^{4}$ Department of Rheumatology, University of Gothenburg, Gothenburg, Sweden \\ ${ }^{5}$ Medical Microbiology, University Medical Center Utrecht, Heidelberglaan 100, 3584 CX Utrecht, \\ The Netherlands
}

Correspondence

Timothy J. Foster

tfoster@tcd.ie

Received 3 November 2008

Revised 3 December 2008

Accepted 8 December 2008
The ability of Staphylococcus aureus to avoid innate immune responses including neutrophilmediated phagocytosis is crucial for the organism to cause infection. This multifactorial process involves several secreted and cell-surface-associated proteins. In this paper we report a novel mechanism of combating neutrophils that involves iron-regulated surface determinant protein $\mathrm{H}$ (IsdH). The IsdH protein is part of a complex that is only expressed under iron-restricted conditions in order to bind haemoglobin and extract and transport haem into the cytoplasm. A null mutant defective in expression of IsdH, and mutants expressing variants of IsdH with substitutions in residues predicted to be involved in ligand binding, were generated from S. aureus 8325-4. The IsdH-defective mutants were shown by several measures to have reduced virulence compared with the wild-type. The mutant was engulfed more rapidly by human neutrophils in the presence of serum opsonins, survived poorly in fresh whole human blood and was less virulent in a mouse model of sepsis. The protective mechanism seems to stem from an accelerated degradation of the serum opsonin $\mathrm{C} 3 \mathrm{~b}$.

\section{INTRODUCTION}

Staphylococcus aureus is normally a harmless commensal of the moist squamous epithelium, where it permanently colonizes about $20 \%$ of the population and is found intermittently in another 50\% (Peacock et al., 2001; Wertheim et al., 2004). It can cause a variety of infections, ranging from superficial skin lesions to more serious and life-threatening invasive diseases such as endocarditis and septic arthritis (Lowy, 1998).

The organism is well endowed with secreted and surfaceassociated factors that combat the initial responses of the host to infection (Foster, 2005; Rooijakkers et al., 2005a).

†These authors contributed equally to this work.

¥This paper is dedicated to the memory of Andrej Tarkowski, who passed away tragically on 1 June 2008.

Abbreviations: GST, glutathione S-transferase; $\mathrm{Hp}-\mathrm{Hb}$, haptoglobinhaemoglobin; HRP, horseradish peroxidase; NEAT motif, NEAr Transporter motif; NHS, normal human serum; PMNL, polymorphonuclear leukocytes.
Four small secreted proteins are known to inhibit migration of neutrophils towards the site of infection. Protein SSL5 inhibits neutrophil rolling on the inflamed endothelial surface of blood vessels (Bestebroer et al., 2007), Eap/ Map blocks migration of neutrophils from blood vessels into tissue (Chavakis et al., 2002), while CHIPS and FLIPr block neutrophil receptors for chemoattractants (de Haas et al., 2004; Prat et al., 2006).

Complement fixation is a crucial aspect of host defences against $S$. aureus, and the organism can interfere with complement activation as well as opsonophagocytosis. The small secreted protein SCIN blocks complement C3 convertases of the classical, lectin and alternative pathways (Rooijakkers et al., 2005a), while Efb and Ecb interfere with the $\mathrm{C} 3 \mathrm{~b}$-containing convertases $\mathrm{C} 3 \mathrm{bBb}$ (alternative pathway $\mathrm{C} 3$ convertase) and the $\mathrm{C} 5$ convertases $\mathrm{C} 4 \mathrm{bC} 2 \mathrm{aC} 3 \mathrm{~b}$ and $\mathrm{C} 3 \mathrm{bC} 3 \mathrm{bBb}$ (Jongerius et al., 2007). Serum plasminogen binds to the bacterial cell surface (Molkanen et al., 2002), where staphylokinase can activate its proteolytic activity, which results in cleavage and destruction of 
opsonic C3b and IgG. There are several well-defined surface components that prevent opsonization and phagocytosis. Most clinical isolates of $S$. aureus elaborate a polysaccharide capsule that blocks opsonin recognition (Thakker et al., 1998). In addition, the biofilm-associated polysaccharide intercellular adhesin has been shown to be anti-phagocytic in Staphylococcus epidermidis (Vuong et al., 2004), and has the potential to be expressed by most strains of $S$. aureus, in which it might also contribute antiphagocytic properties. Protein A binds the Fc region of IgG (Uhlen et al., 1984) and prevents both opsonophagocytosis and complement fixation (Gemmell et al., 1991).

The ability of clumping factor A to bind fibrinogen to the bacterial cell surface is also anti-phagocytic (Higgins et al., 2006; Rooijakkers et al., 2005b). In addition, it can capture and activate serum complement regulator factor I and convert $\mathrm{C} 3 \mathrm{~b}$ to $\mathrm{iC} 3 \mathrm{~b}$ without the serum cofactor factor $\mathrm{H}$ (Cunnion et al., 2004; Hair et al., 2008). This could serve as a mechanism to prevent C3 convertase formation and terminal pathway activation (Cunnion et al., 2004).

Previous studies of anti-phagocytic properties of S. aureus have been performed with bacteria growing in iron-rich laboratory media. Recently, it has become apparent that $S$. aureus expresses on its surface several covalently anchored proteins, the prime function of which appears to be capture of haem from haptoglobin-haemoglobin $(\mathrm{Hp}-\mathrm{Hb})$ in serum and transportation of the iron-carrying compound into the cytoplasm, where $\mathrm{Fe}^{2+}$ is released (Mazmanian et al., 2003; Skaar \& Schneewind, 2004). The iron-regulated surface determinant A (IsdA) protein is multifunctional. As well as being required for haem uptake it can bind several different plasma proteins (Clarke et al., 2004), it promotes adhesion to desquamated epithelial cells (Clarke et al., 2006), it protects against the bactericidal effect of lactoferrin (Clarke \& Foster, 2008), and it contributes to the ability of $S$. aureus to colonize skin, where its negative charge reduces susceptibility to bactericidal lipids and cationic antimicrobial peptides (Clarke et al., 2007). The ligand binding activity of IsdA is conferred by a single $\mathrm{N}$-terminal NEAr Transporter (NEAT) motif (Andrade et al., 2002), whilst the hydrophilic surface charge is conferred by a C-terminal domain (Clarke et al., 2007). The largest of the Isd proteins, IsdH, contains three NEAT motifs and binds strongly to $\mathrm{Hp}-\mathrm{Hb}$. This is the first step in extracting haemin and transporting it into the cytoplasm as a source of iron (Skaar \& Schneewind, 2004). The structure of the NEAT1 motif of IsdH has been solved recently (Pilpa et al., 2006). It comprises two five-stranded $\beta$-sheets that form a $\beta$-sandwich fold. Residues located in a loop between $\beta$-strands $1 \mathrm{~b}$ and 2 are predicted to be involved in ligand binding (Pilpa et al., 2006). Given the role of IsdA in evading innate immune defences (Clarke \& Foster, 2008; Clarke et al., 2007), it was interesting to determine whether IsdH had similar properties.

In this paper we investigated the role of the IsdH protein in pathogenesis and discovered that by facilitating enhanced conversion of $\mathrm{C} 3 \mathrm{~b}$ to $\mathrm{iC} 3 \mathrm{~b}$ and $\mathrm{C} 3 \mathrm{~d}$ it has a strong influence on the ability of $S$. aureus to survive neutrophil uptake and killing.

\section{METHODS}

Bacterial strains and growth conditions. DNA cloning was performed in Escherichia coli XL-1 Blue (Stratagene). Bacteria were grown on Luria broth or agar incorporating ampicillin (Amp; $100 \mu \mathrm{g}$ $\mathrm{ml}^{-1}$ ). Lactococcus lactis strains used were MG1363 (Hartford et al., 2001) carrying pKS80 and L. lactis MG1363 pKS80-isd $H^{+}$, which was constructed as described below. L. lactis cells were grown on M17 agar or in M17 broth (Difco) incorporating $0.5 \%$ glucose (GM17) and erythromycin (Em; $10 \mu \mathrm{g} \mathrm{ml}^{-1}$ ) at $30{ }^{\circ} \mathrm{C}$ without shaking. S. aureus strains used were: 8325-4 (Novick, 1967); DU5875 8325-4 spa:: Tc ${ }^{\mathrm{r}}$ (Jonsson et al., 1995); DU6018 (8325-4 isdH::Em ${ }^{\mathrm{r}}$ ), which was constructed as described below; DU6019 (8325-4 spa:: Tc $^{\mathrm{r}}$

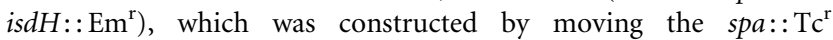
mutation into DU6018 by generalized phage transduction using phage 85 (Foster, 1998); and two amino acid substitution mutants, DU6020 (8325-4 isdH2) and DU6021 (8325-4 isdH3), also described below. The fidelity of mutants and transductants was verified by Western immunoblotting of solubilized cell wall proteins with rabbit anti-IsdH41-321 polyclonal antibodies and with horseradish peroxidase (HRP)-conjugated goat anti-rabbit IgG (Dako).

For optimal expression of IsdH, S. aureus was grown in RPMI 1640 (Cambrex Bio Science) containing $2 \mathrm{mM}$ glutamine and buffered with HEPES (Cambrex Bio Science), pH 7.3, with shaking at 120 r.p.m. at $37{ }^{\circ} \mathrm{C}$. In the growth curve experiment, stationaryphase RPMI cultures served as inocula to fresh RPMI 1640 to prevent carryover of $\mathrm{Fe}^{3+}$ and to use cells that were already starved of $\mathrm{Fe}^{3+}$. For routine growth, trypticase soy broth (TSB) and agar (TSA) or brain-heart infusion broth and agar were used, incorporating chloramphenicol $\left(\mathrm{Cm} ; 10 \mu \mathrm{g} \mathrm{ml}^{-1}\right)$, Em $\left(10 \mu \mathrm{g} \mathrm{ml}^{-1}\right)$ or tetracycline (Tc; $2 \mu \mathrm{g} \mathrm{ml}^{-1}$ ) when needed.

Antibodies. Antibodies reactive against IsdH41-321 and IsdB48-477 were obtained by immunizing specific-pathogen-free rabbits with hexahistidine-tagged proteins (Roche et al., 2003). Anti-S. aureus whole-cell antibodies were generated by immunizing rabbits with heat-killed 8325-4 cells. The sources of commercial antibodies are described in the appropriate procedures.

Construction of the isdH null mutant and cloning of the isdH gene. A $949 \mathrm{bp}$ fragment comprising bases 50-998 of isdH was amplified from S. aureus 8325-4 genomic DNA using Pfu polymerase (Promega) and primers $\mathrm{F}$ isdH50 and $\mathrm{R}$ isdH998 (Table 1). The purified fragment was cleaved at the PCR-introduced EcoRI and BamHI sites and cloned into the suicide vector pAZ106 (Kemp et al., 1991) digested with the same enzymes. The chimeric plasmid was transformed by electroporation into S. aureus RN4220 (Kreiswirth et al., 1983). Transformants that occurred by homologous recombination with the $i s d H$ gene, causing its disruption and creating a isdH: : lacZ transcriptional fusion (Kemp et al., 1991), were selected for resistance to $\mathrm{Em}$. The isdH::lacZ fusion was subsequently transduced into $S$. aureus 8325-4 using phage 85 (Foster, 1998), selecting for resistance to $\mathrm{Em}$. The fidelity of transductants was verified by Southern blotting and by Western immunoblotting of solubilized cell wall proteins with anti-IsdH41-321 polyclonal antibodies.

A $3.5 \mathrm{~kb}$ fragment containing the entire $S$. aureus $8325-4$ isdH gene, including $676 \mathrm{bp}$ of upstream sequence and $183 \mathrm{bp}$ of downstream sequence, was amplified with $P f u$ polymerase (Promega) using primers $\mathrm{F}$ is $d H-676$ and $\mathrm{R}$ is $d H+183$ (Table 1), incorporating $E c o$ RI and BamHI restriction sites. The amplimer was ligated into the shuttle plasmid pCU1 (Augustin et al., 1992) that had been digested 
Table 1. Primer sequences used for recombinant protein construction and overlap primer PCR mutagenesis

F corresponds to forward primer and R to reverse primer. Restriction sites (BamHI, HindIII and SmaI) and mismatched nucleotides are underlined.

\begin{tabular}{|c|c|}
\hline Primer name & Sequence \\
\hline $\mathrm{F}$ isdH50 & 5'-CGCGGATCCCAACTCTAGGCGTTGCATCGG-3' \\
\hline $\mathrm{R}$ isd $H 998$ & 5'-CCGGAATTCGCATCTTGTAGTGATTCATCTGCTG-3' \\
\hline $\mathrm{F}$ is $d H-676$ & 5'-CCGGAATTCGAAGTCATTGATCAACCTAATTC-3' \\
\hline $\mathrm{R}$ isdH+183 & 5'-CCGGGATCCGTAACCACAACAATGAATCCAAA-3' \\
\hline $\mathrm{F}$ isdH5 & 5'-CGCGGATCCACAAACATCACCCAAAATTAAGG-3' \\
\hline $\mathrm{R}$ isd $\mathrm{H} 2688$ & 5'-CGCGGATCCTTATTTAGATTCTTTTCTGAATTTAG-3' \\
\hline F1 rIsdH41 BamHI & 5'-CCGGGATCCGCAGAAAATACAAATACTTC-3' \\
\hline R1 rIsdH321SmaI & 5'-CCGCCCGGGTTATTGATTAACATCCGACTG-3' \\
\hline F2 rIsdH322BamHI & 5'-CCGGGATCCCAGTATCCACCAGCAGATG-3' \\
\hline R2 rIsdH540SmaI & 5'-CCGCCCGGGTTATGTAGGTGTAACATTTTCAAAT-3' \\
\hline F3 rIsdH541 BamHI & 5'-CCGGGATCCAATGATCAATTAACAGATTTACAA-3' \\
\hline R3 rIsdH860SmaI & 5'-CCGCCCGGGTTACATTTTAGATTGACTAAGTTTGT-3' \\
\hline F5 Y126A & 5'-ATGAAACGCAGTACGCTCACTTTTTCAGCA-3' \\
\hline R5 Y126A & 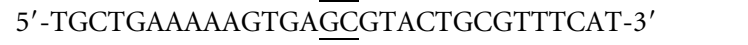 \\
\hline F6 H127E & 5'-ACGCAGTACTATGAATTTTTCAGCATC-3' \\
\hline R6 H127E & 5'-GATGCTGAAAAATTTCATAGTACTGCGT-3' \\
\hline F7 F128A & 5'-GCAGTACTATCACGCTTTCAGCATCAAAG-3' \\
\hline R7 F128A & 5'-CTTTGATGCTGAAAGCGTGATAGTACTGC-3' \\
\hline F15 D206A & 5' -CGACTCAAATTGATGCETGGAGAAGAAACAA-3' \\
\hline R15 D206A & 5' -TTGTTTCTTCTCCAGCATCAATAAGAGTCG-3' \\
\hline F16 Y126A/F128A & 5'-CGCAGTACGCTCACGCTTTCAGCAT-3' \\
\hline R16 Y126A/F128A & 5'-ATGCTGAAAGCGTGAGCGTACTGCG-3' \\
\hline F17 Y126A/H127E/F128A & 5'-ACGCAGTACGCTGAAGCTTTCAGCATC-3' \\
\hline R17 Y126A/H127E/F128A & 5'-GATGCTGAAAGCTTCAGCGTACTGCGT-3' \\
\hline F18 isdH-676 BamHI & 5'-CCGGGATCCGAAGTCATTGATCAACCTAATTC-3' \\
\hline R18 isdH963 HindIII & 5'-CCGGAATTCTTGATTAACATCCGACTG-3' \\
\hline R19 isdH1620 HindIII & 5'-CCGGAATTCTGTAGGTGTAACATTTTCAAAT-3' \\
\hline F20 EcoRV D105 I106 & 5'-AAGAACATGATATC彑GGTCCAAGAGAAC-3' \\
\hline R20 EcoRV D105 I106 & 5' - GTTCTCTTGGACCㅡ- \\
\hline F21 SpeI T256 S257 & 5'-ACAAACACGAATACTAGTAATCAAAATATATC-3' \\
\hline R21 SpeI T256 S257 & 5'-GATATATTTTGATTACTAGTATTCGTGTTTGT-3' \\
\hline
\end{tabular}

with the same enzymes. A transformant designated pCU1-isd $H^{+}$was selected in E. coli for resistance to Amp. The pCU1-is $d H^{+}$plasmid was transformed by electroporation into S. aureus RN4220, selecting for $\mathrm{Cm}$ resistance, and was transduced into DU6018 (S. aureus 8325-4 isdH:: $\mathrm{Em}^{\mathrm{r}}$ ) by generalized phage transduction using phage 85 (Foster, 1998), selecting for resistance to $\mathrm{Cm}$ and $\mathrm{Em}$.

The isdH gene was also cloned into the L. lactis expression vector pKS80 (Hartford et al., 2001). The ORF from the ATG codon to the stop codon of $8325-4$ is $\mathrm{H}$ was amplified by PCR using primers $\mathrm{F}$ isdH5 and $\mathrm{R}$ isd 2688 (Table 1), with a BamHI site introduced in the forward primer that allowed the is $d H$ gene to be fused to the translation initiation signals of pKS80. The plasmid pKS80-is $d H^{+}$was transformed into L. lactis MG1363 (Hartford et al., 2001), selecting for resistance to Em.

Expression and purification of recombinant IsdH and IsdB. The region of the 8325-4 is $\mathrm{H}$ gene encoding amino acids $41-321$ and the is $d B$ gene encoding residues 48-477 were PCR-amplified from genomic DNA using $P f u$ polymerase (Promega) and primers F1 rIsdH41BamHI and R1 rIsdH321SmaI for rIsdH41-321 (Table 1) or primers described previously for rIsdB48-477 (Roche et al., 2003), incorporating BamHI and SmaI restriction sites. The PCR products were cloned into the N-terminal glutathione $S$-transferase (GST) fusion expression vector pGEX-4T2 (Amersham Biosciences). The GST fusion protein was expressed in E. coli BL21 (DE3) (Amersham Biosciences) and purified using a GSTrap column (Amersham Biosciences) as previously described (O'Seaghdha et al., 2006).

Recombinant IsdH mutants. Single amino acid substitutions were introduced in pGEX-4T2 IsdH41-321 by overlap primer PCR mutagenesis with $P f u$ polymerase (Promega). Primers used for the mutagenesis were F5/R5 (Y126A), F6/R6 (H127E), F7/R7 (F128A), F15/R15 (D206A) (Table 1). The paired forward primer $\left(F_{X}\right)$ and the reverse primer $\left(R_{X}\right)$ for the mutagenesis were complementary. In the first step, the mutation was introduced into two overlapping PCR products using primers $F 1 / R_{X}, F_{X} / R 1$ and pGEX-4T2 IsdH41-321 as template. These PCR products were combined as the template for the second PCR step, which used the flanking primers F1 and R1 (Table 1). The PCR fragment incorporating the $i s d H$ point mutation was cloned at the BamHI and SmaI sites into pGEX-4T2. Double amino acid substitutions Y126A/F128A were introduced using primers F16/ R16 and pGEX-4T2 IsdH41-321 Y126A as template, and triple amino acid substitutions Y126A/H127E/F128A were introduced using primers F17/R17 and pGEX-4T2 IsdH41-321 Y126A/F128A as 
template. PCR products from the second PCR step amplified by using primers $\mathrm{F} 1$ and $\mathrm{R} 1$ and incorporating the double or triple amino acid substitutions were cloned into pGEX-4T2 at the BamHI and SmaI sites.

S. aureus missense mutations. A 1739 bp fragment including 676 bases upstream of isdH and 963 bases of isdH was amplified from $S$. aureus 8325-4 genomic DNA using Pfu polymerase (Promega) and primers F18 and R18 (Table 1). The introduced $5^{\prime}$ restriction sites facilitated cloning of the PCR fragment between BamHI and HindIII sites in pBluescript II SK to produce pBluescript is $d H^{\prime}$. A same-sense nucleotide mutation in is $d H$ was introduced to create an EcoRV restriction site at codons for D105/I106 in isdH by overlap primer PCR mutagenesis using primers F20 and R20, flanking primers F18 and R18 (Table 1), and pBluescript is $d H^{\prime}$ as template. The PCR product incorporating the new EcoRV site was cloned into pBluescript II SK at the BamHI and HindIII sites. Amino acid substitutions Y126A/H127E/F128A were introduced by sequential overlap primer PCR mutagenesis by using primers F5, R5, F16, R16, F17 and R17, flanking primers F18 and R18 (Table1), and pBluescript is $d H^{\prime} E c o \mathrm{RV}$ as template. The PCR product incorporating IsdH Y126A/H127E/F128A amino acid substitutions was cloned into pBluescript II SK at the BamHI and HindIII sites.

The is $d H$ gene incorporating bases $121-1620$ of is $d H$ was amplified from S. aureus 8325-4 genomic DNA using $P f u$ polymerase and primers F1 and R19 (Table 1). The 1500 bp PCR fragment was cloned between BamHI and HindIII sites in pBluescript II SK, which was used as template to create same-sense mutations and a new SpeI restriction site by introducing three nucleotide mutations at codons for T256 and S257 by using primers F21 and R21 and flanking primers F1 and R19 (Table 1). The PCR product incorporating the SpeI site was cloned into pBluescript II SK at the BamHI and HindIII sites. The D206A amino acid substitution was subsequently introduced by overlap primer PCR mutagenesis using primers F15 and R19, and flanking primers F1 and R15 (Table 1), using pBluescript is $d H$ carrying the SpeI mutations as the template. The PCR product incorporating the IsdH D206A amino acid substitution was cloned into pBluescript II SK at the BamHI and HindIII sites.

pBluescript II containing the mutated is $d H$ fragments was then ligated with pTSermC (Fitzgerald et al., 2006) using the BamHI sites in both plasmids. The resulting temperature-sensitive shuttle plasmid was transferred into S. aureus 8325-4. The Y126A/H127E/F128A amino acid substitutions with the adjacent EcoRV site or D206A amino acid substitution with the adjacent SpeI site were integrated into the 83254 chromosomal isdH gene by allelic replacement (Foster, 1998). Briefly, the plasmid-bearing strains were grown to saturation in broth containing Em $\left(10 \mu \mathrm{g} \mathrm{ml}^{-1}\right)$ at $30{ }^{\circ} \mathrm{C}$. The culture was diluted and plated on TSA containing Em at $44^{\circ} \mathrm{C}$ to select integrants. Colonies were picked and grown in broth lacking antibiotic at $30{ }^{\circ} \mathrm{C}$ to encourage initiation of plasmid replication. The stationary phase culture was diluted 1:100 in TSB without antibiotic and grown at $44{ }^{\circ} \mathrm{C}$ to saturation. The alternating growth under permissive and restrictive conditions was repeated twice before cultures were plated for single colonies on TSA lacking antibiotic. Genomic DNA was isolated from Em-sensitive colonies, and a PCR product containing the codons for IsdH41-321 was amplified and checked for the presence of the novel EcoRV or SpeI sites to identify putative recombinants, followed by DNA sequencing. Strain DU6020 8325-4 isdH2 has the Y126A/H127E/F128A substitutions and DU6021 8325-4 isdH3 has the D206A substitution.

Surface expression of IsdH by S. aureus. S. aureus $8325-4$ or 8325-4 isd $H$ mutant strains were grown in RPMI 1640 medium for the indicated times at $37^{\circ} \mathrm{C}$, harvested by centrifugation and resuspended in PBS. Microtitre plates were coated with $5 \times 10^{7}$ cells per well, incubated at $37{ }^{\circ} \mathrm{C}$ overnight and then blocked with $2 \%$ BSA-PBS for $1 \mathrm{~h}$ at $37{ }^{\circ} \mathrm{C}$. In order to neutralize the ability of protein
A to bind IgG, wells were incubated with $100 \mu$ l bovine IgG $(200 \mu \mathrm{g}$ $\mathrm{ml}^{-1}$ ) for $1 \mathrm{~h}$ at $22{ }^{\circ} \mathrm{C}$. After washing with PBS Tween-20 (PBST), $100 \mu \mathrm{l}$ anti-isdH41-321 antibody $\left(10 \mu \mathrm{g} \mathrm{ml}^{-1}\right)$ was added to the wells and incubated for $90 \mathrm{~min}$. Detection of bound antibody was performed by addition to the wells of HRP-labelled goat anti-rabbit IgG antibody (Dako, 1:1000) followed by $o$-phenylenediamine dihydrochloride. Rabbit preimmune IgG was tested as a control. The binding of wild-type and mutant bacteria from different time points to the wells was shown to be equivalent using antibodies to whole $S$. aureus cells in ELISAs.

Western immunoblotting. $S$. aureus cells were grown to stationary phase (18 h) in RPMI 1640 medium, whereas L. lactis cells were grown to stationary phase $(16 \mathrm{~h})$ in GM17 broth. Cells were harvested, washed in PBS and resuspended at an $\mathrm{OD}_{600}$ of 40 in $20 \mathrm{mM}$ Tris, $\mathrm{pH} 8.0$, containing $10 \mathrm{mM} \mathrm{MgCl}_{2}, 30 \%$ raffinose and Complete Mini Protease Inhibitor Cocktail (Roche). Cell-wall-associated proteins of $S$. aureus were solubilized by lysostaphin $\left(200 \mu \mathrm{g} \mathrm{ml}^{-1}\right)$ (Roche et al., 2003), whereas those of L. lactis were released by digestion with mutanolysin $\left(500 \mathrm{U} \mathrm{ml}^{-1}\right)$ and lysozyme $\left(200 \mu \mathrm{g} \mathrm{ml}^{-1}\right.$ ) (Hartford et al., 2001). A $20 \mu \mathrm{l}$ sample was boiled in final sample buffer, electrophoresed in a $10 \%$ SDS-PAGE gel and transferred to a PVDF membrane (Roche et al., 2003) by the wet transfer method. The membrane was blocked in TS buffer $(10 \mathrm{mM}$ Tris/ $\mathrm{HCl}, 0.9 \% \mathrm{NaCl}$, $\mathrm{pH}$ 7.4) containing $10 \%$ skimmed milk for $20 \mathrm{~h}$ at $4{ }^{\circ} \mathrm{C}$. Polyclonal anti-IsdH41-321 antibodies (20 $\mathrm{ng} \mathrm{ml}^{-1}$ ) (Roche et al., 2003) and anti-IsdB48-477 antibodies (20 $\mathrm{ng} \mathrm{ml}^{-1}$ ) (Roche et al., 2003) were used to detect IsdH from S. aureus 8325-4 and L. lactis (pKS80-isd $H^{+}$) and IsdB from $S$. aureus. Bound antibodies were recognized with protein A coupled to HRP $\left(2 \mu \mathrm{g} \mathrm{ml}{ }^{-1}\right)$ (Sigma) and LumiGLO chemiluminescence substrate (New England Biolabs) and exposed to X-Omat autoradiographic film (Kodak).

Solid-phase binding assay. $\mathrm{Hp}-\mathrm{Hb}$ complexes were prepared by mixing haptoglobin (Sigma) with haemoglobin (Sigma) at a $1: 1$ molar ratio for $1 \mathrm{~h}$ at $22{ }^{\circ} \mathrm{C}$ before coating the wells. Microtitre plates (MaxiSorp) were coated with $25 \mathrm{nM} \mathrm{Hp}-\mathrm{Hb}$ complex in $100 \mu \mathrm{l}$ $50 \mathrm{mM}$ sodium carbonate buffer, $\mathrm{pH} 9.5$, overnight at $4{ }^{\circ} \mathrm{C}$. Coated wells were washed three times with PBS $(10 \mathrm{mM}$ sodium phosphate, $\mathrm{pH} 7.4$, containing $0.13 \mathrm{M} \mathrm{NaCl}$ ) and blocked with $5 \%$ skimmed milk in PBS for $2 \mathrm{~h}$ at $37{ }^{\circ} \mathrm{C}$. Following three washes with PBS, various concentrations of purified GST-fusion rIsdH proteins in $2 \%$ skimmed milk in PBS were added and incubated for $2 \mathrm{~h}$ at $37^{\circ} \mathrm{C}$. Wells were washed with PBS, and bound IsdH was detected by incubation with $0.2 \mu \mathrm{g}$ HRP-conjugated goat polyclonal anti-GST antibodies (Abcam) per well in $2 \%$ skimmed milk in PBS for $1 \mathrm{~h}$ at $37{ }^{\circ} \mathrm{C}$. The reciprocals of the binding experiments were performed by coating microtitre wells with $5 \mu \mathrm{M}$ GST-fusion IsdH proteins overnight at $4{ }^{\circ} \mathrm{C}$ in $100 \mu \mathrm{l} 50 \mathrm{mM}$ sodium carbonate buffer, $\mathrm{pH}$ 9.5. After blocking with $5 \%$ skimmed milk in PBS, the wells were incubated with increasing amounts of $\mathrm{Hp}-\mathrm{Hb}$ in $2 \%$ skimmed milk in PBS for $2 \mathrm{~h}$ at $37{ }^{\circ} \mathrm{C}$. Bound proteins were detected by incubation with $127 \mathrm{ng}$ per well of polyclonal rabbit anti-haemoglobin antibodies (Dako) in $2 \%$ skimmed milk in PBS for $1 \mathrm{~h}$ at $37{ }^{\circ} \mathrm{C}$. After three washes with PBS, HRP-conjugated goat anti-rabbit antibodies (Dako, $1: 1000)$ in $2 \%$ skimmed milk in PBS were added for $1 \mathrm{~h}$ at $37^{\circ} \mathrm{C}$. After three washes, $100 \mu \mathrm{l} 3,3^{\prime}, 5,5^{\prime}$-tetramethylbenzidine (TMB) $\left(0.1 \mathrm{mg} \mathrm{ml}^{-1}\right.$; Sigma) prepared in $0.05 \mathrm{M}$ phosphatecitrate buffer containing $0.006 \%$ (v/v) hydrogen peroxide was added, and plates were developed for $10 \mathrm{~min}$. The reaction was stopped by the addition of $50 \mu \mathrm{l} 2 \mathrm{M} \mathrm{H}_{2} \mathrm{SO}_{4}$ to each well. Plates were read at $450 \mathrm{~nm}$ using an ELISA plate reader (Multisckan). Half-maximum binding values reported for all ELISA-type binding assays were predicted using GraphPad Prism software.

Isolation of human polymorphonuclear leukocytes (PMNL). Fresh whole blood was obtained in sodium citrate-containing tubes 
from healthy volunteers, and mixed with an equal volume of PBS. This was centrifuged through step gradients of Histopaque $(\rho=1.077)$ (Sigma) and Ficoll-paque $(\rho=1.119)$ (Amersham), and PMNL were aspirated from the buffy coat between the Ficoll and Histopaque layers. Cells were washed in RPMI 1640 medium [containing $10 \mathrm{mM}$ HEPES, $25 \mathrm{mM}$ glutamine and $0.05 \%(\mathrm{v} / \mathrm{v})$ human serum albumin] (Gibco-BRL) and resuspended in water. After a $30 \mathrm{~s}$ osmotic shock to lyse contaminating red blood cells, $10 \times$ PBS was added and the cells were again washed in RPMI 1640. PMNL were counted in a Neubauer haemocytometer (Brand) and adjusted to $5 \times 10^{6}$ cells ml $^{-1}$ in RPMI 1640. This procedure typically yielded $>97 \%$ PMNL with $>95 \%$ viability, as determined by Trypan Blue exclusion. All reagents used in PMNL isolation were certified endotoxin-free.

Phagocytosis. The phagocytosis assay was performed as previously described (Higgins et al., 2006). Whole S. aureus cells grown for $18 \mathrm{~h}$ in RPMI 1640 medium and L. lactis strains grown for $16 \mathrm{~h}$ in GM17 broth were washed twice in PBS and labelled with $30 \mu \mathrm{g}$ FITC $\mathrm{ml}^{-1}$ in PBS for $1 \mathrm{~h}$ at $37^{\circ} \mathrm{C}$ with shaking. This procedure did not affect viability or the ability to bind to fibrinogen (data not shown). Cells were washed three times in PBS and enumerated in a Neubauer haemocytometer (Brand), adjusted to $1 \times 10^{9}$ c.f.u. $\mathrm{ml}^{-1}$ in RPMI 1640 and stored frozen at $-20{ }^{\circ} \mathrm{C}$. Bacteria were thawed on ice and diluted to $5 \times 10^{7}$ c.f.u. $\mathrm{ml}^{-1}$ in RPMI 1640. Human serum was diluted in RPMI 1640. Bacteria $(50 \mu \mathrm{l})$ were opsonized in $10 \mu \mathrm{l}$ diluted serum for $10 \mathrm{~min}$ at $37^{\circ} \mathrm{C}$, followed by addition of $50 \mu \mathrm{l}$ prewarmed PMNL and incubation at $37{ }^{\circ} \mathrm{C}$ with vigorous shaking. The final bacteria: PMNL ratio was $10: 1$. Reactions were stopped after $5-15 \mathrm{~min}$ by addition of $100 \mu \mathrm{l}$ ice-cold $1 \%(\mathrm{w} / \mathrm{v})$ paraformaldehyde in PBS. The percentage of PMNL-bearing FITC-labelled bacteria (percentage phagocytosis) was determined by flow cytometric analysis of 5000 cells with manual gating using a FACScan flow cytometer (Becton Dickinson). The percentage of internalized bacteria was determined by Trypan Blue quenching of extracellular fluorescence (Higgins et al., 2006; Rooijakkers et al., $2005 \mathrm{~b}$ ). Addition of $20 \mu \mathrm{g} \mathrm{ml}^{-1}$ (final concentration) Trypan Blue (Merck) demonstrated that $>85 \%$ bacteria associated with PMNL were internalized (data not shown). Confocal microscopy has also been used to show that FITC-labelled bacteria are intracellular (Rooijakkers et al., 2005b). Samples were prepared in triplicate and all experiments were repeated four times using the blood of different donors. Statistical analyses were performed using Student's $t$ test and $P$ values $<0.01$ were considered significant.

Bactericidal assay. The ability of $S$. aureus to survive in human blood was measured as described elsewhere (Dombek et al., 1999). Briefly, $S$. aureus 8325-4 and its mutants grown in RPMI 1640 to stationary phase were diluted in PBS, and $100 \mu \mathrm{l}\left(5 \times 10^{2}\right.$ c.f.u. $)$ was added to $1.25 \mathrm{ml}$ fresh blood obtained from healthy human volunteers that had been treated with $50 \mu \mathrm{g} \mathrm{ml}^{-1}$ of the anti-coagulant hirudin (Refludan, Pharmion). Blood was drawn from donors lacking anti-IsdH antibodies. A portion of each culture was plated on agar to determine the input c.f.u. Tubes were incubated at $37{ }^{\circ} \mathrm{C}$ with gentle rocking, and after $3 \mathrm{~h}$ serial dilutions were plated to determine the number of surviving c.f.u. To exclude the possibility that the viable counts were due to differences in the ability to grow in plasma, growth curves for each strain were produced and were indistinguishable.

Experimental sepsis. Seven-week-old female NMRI mice were obtained from B\&K Universal and maintained at the animal facility of the Department of Rheumatology and Inflammation Research, University of Göteborg, Sweden. All mice were maintained according to the local ethical board animal husbandry standards. The mice were housed 10 to a cage under standard conditions of temperature and light, and were fed standard laboratory chow and water ad libitum.

Bacteria were grown on RPMI 1640 agar plates with L-glutamine, glucose and sodium bicarbonate for $48 \mathrm{~h}$, and were harvested and kept frozen at $-20{ }^{\circ} \mathrm{C}$ in PBS containing 5\% BSA and $10 \%$ DMSO. Before injection into animals, the bacterial suspensions were thawed, washed in PBS and adjusted to appropriate cell concentrations. Mice received inoculations in the tail vein of 9.7-10.2 $\times 10^{8}$ c.f.u. $8325-4$ wild-type or $10.2-10.4 \times 10^{8}$ c.f.u. DU6018 in $0.2 \mathrm{ml}$ bacterial suspension. The number of viable bacteria was measured in conjunction with each challenge by counting colonies following culture at $37{ }^{\circ} \mathrm{C}$ for $24 \mathrm{~h}$ on blood agar plates.

The clinical evaluation was performed in a blinded manner. The overall condition of each mouse was examined by assessing signs of systemic inflammation, i.e. weight decrease, reduced alertness, and ruffled coat. In cases of severe systemic infection, when a mouse was judged too ill to survive another $24 \mathrm{~h}$, it was killed by cervical dislocation and considered dead due to sepsis. Statistical evaluation was done by the logrank test of survival analysis; $P<0.05$ was considered to be significant.

$\mathbf{C} 3 \mathbf{b} /$ ic $3 \mathbf{b}$ conversion to $\mathbf{C} 3 \mathbf{d}$ - flow cytometry. S. aureus strains were grown in RPMI 1640 for $18 \mathrm{~h}$ at $37^{\circ} \mathrm{C}$, harvested by centrifugation and suspended in HEPES buffer, $\mathrm{pH}$ 7.4. Cells $\left(5 \times 10^{7}\right)$ were incubated with $10 \%$ pooled normal human serum (NHS) in MgEGTA for the indicated times at $37{ }^{\circ} \mathrm{C}$. Complement activation was halted with $0.01 \mathrm{M}$ EDTA, pH 7.4. After washing in HEPES buffer containing $0.01 \mathrm{M}$ EDTA, pH 7.4, cells were incubated with polyclonal anti-C3c antibody (Dako) $\left(100 \mu \mathrm{l}\right.$ of $\left.100 \mu \mathrm{g} \mathrm{ml} \mathrm{m}^{-1}\right)$ or polyclonal anti-C3d antibodies (Dako) $(10 \mu \mathrm{g})$ in $0.1 \% \mathrm{BSA} / \mathrm{PBS}$ for $1 \mathrm{~h}$ on ice. After washing with PBS, cells were incubated with FITClabelled swine anti-rabbit IgG antibodies (Dako) $(100 \mu \mathrm{l}$ of $60 \mu \mathrm{g}$ $\mathrm{ml}^{-1}$ in $0.1 \% \mathrm{BSA} / \mathrm{PBS}$ for $1 \mathrm{~h}$ on ice), then washed with PBS. Bound antibodies were recognized by measuring the mean fluorescence units of 10000 cells on a FACScan flow cytometer (Becton Dickinson).

\section{RESULTS}

\section{Inactivation of the isdH gene}

The is $d H$ gene was inactivated by directed integration of plasmid pAZ106 (forming is $H::$ pAZ106Em ${ }^{\mathrm{r}}$ ). The entire isd $\mathrm{H}$ gene including its promoter and fur box for upregulation under iron-limited conditions was cloned into the shuttle vector pCU1 forming pCU1-isd $H^{+}$. Expression of IsdH was measured by Western immunoblotting of proteins solubilized from the cell wall with lysostaphin during protoplast formation. A single band of approximately $140 \mathrm{kDa}$ bound to anti-IsdH41-321 antibodies in the wild-type and the mutant carrying the complementing plasmid pCU1-isd $\mathrm{H}^{+}$, but was missing in the IsdH-defective mutant (Fig. 1a). Expression of another Isd protein, IsdB (Fig. 1d), and another surface protein, protein A (not shown), was not altered in any of the genetically manipulated strains. In addition, processing of IsdH to the cell surface in the complement null mutant was not impeded, because all of the protein was located in the wall fraction (data not shown). L. lactis pKS80-isd $H^{+}$also expressed an immunoreactive protein of approximately $120 \mathrm{kDa}$ (Fig. $1 \mathrm{~b}$ ).

\section{IsdH is surface-exposed and expressed predominantly in stationary phase}

In order to determine in which phase of growth IsdH is expressed, S. aureus 8325-4 and the isdH mutant were 
(a)

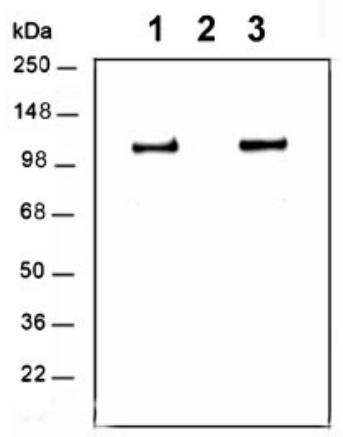

(c)

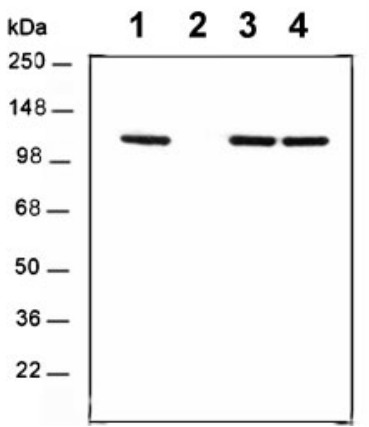

(b)

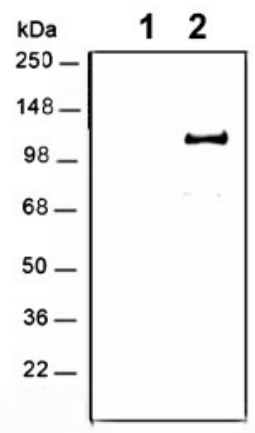

(d)

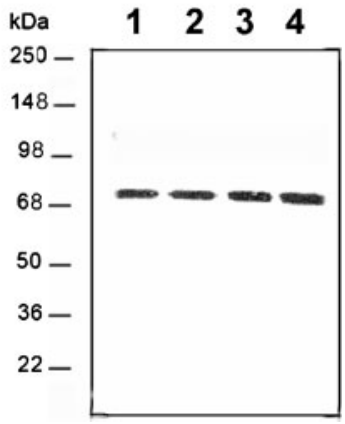

Fig. 1. Western immunoblotting. (a) S. aureus 8325-4 (lane 1), 8325-4 isdH (lane 2) and 8325-4 isdH (pCU1-isd $H^{+}$) (lane 3) were grown to stationary phase in RPMI 1640. Cells were treated with lysostaphin, and the solubilized surface proteins were subjected to SDS-PAGE followed by transfer to membranes and probing with anti-IsdH41-321 antibodies and peroxidase-conjugated protein A. (b) L. lactis (pKS80) and L. lactis (pKS80isd $\mathrm{H}^{+}$) cells (lanes 1 and 2 , respectively) were treated with mutanolysin and lysozyme to release cell-wall-associated proteins, which were separated by SDS-PAGE, transferred to membranes and probed with anti-IsdH41-321 antibodies and HRP-conjugated protein A. (c) Lane 1, S. aureus 8325-4; lane 2, 8325-4 isd $\mathrm{H}: \mathrm{Em}^{\mathrm{r}}$; lane 3, 8325-4 isd H2; and lane 4, 8325-4 isdH3 processed as in (a) and probed with anti-lsdH41-321 antibodies and HRP-conjugated protein A. (d) Lane 1, S. aureus 8325-4; lane 2, 8325-4 isdH: : Em ${ }^{\mathrm{r}}$; lane 3, 8325-4 isd H2; and lane 4, 8325-4 isd $\mathrm{H3}$ processed as in (a) and probed with anti-IsdB48-477 antibodies and HRP-conjugated protein $\mathrm{A}$.

grown in RPMI and sampled periodically. Bacterial cells were normalized to the same optical density, and cells were absorbed to the surface of wells of an ELISA plate and probed with anti-IsdH41-321 antibodies. Control wells were probed with anti-S. aureus whole-cell antibodies to show that equal numbers of cells were present in each sample. Fig. 2 shows that the IsdH protein was expressed at a higher level in the stationary phase of growth $(18 \mathrm{~h})$ than the exponential phase $(3 \mathrm{~h})$, and furthermore indicates that the N-terminal region is surface-exposed.

\section{Expression of IsdH inhibits killing by neutrophils} in whole blood

In order to determine whether expression of IsdH contributes to survival of $S$. aureus in whole blood, bacterial cells were incubated in blood obtained from 10 donors. Recombinant hirudin (Refludan) was used as the anticoagulant in order to preserve complement activity. None of the 10 selected donors had significant anti-IsdH antibodies as determined by ELISA (data not shown). Protein A is known to be an important anti-phagocytic factor, so the ability of the isdH mutant to survive was compared with that of a spa mutant, and a mutant defective in both spa and isdH. Furthermore, the isdH mutant bearing the pCU1-isd $H^{+}$complementing plasmid was included.

With wild-type S. aureus $8325-4$, an average of $56 \pm 6.5 \%$ of the initial inoculum survived in blood for $3 \mathrm{~h}$ (Fig. 3a). The survival of the is $d H$ mutant was severely compromised, with only $4.6 \pm 2.8 \%$ surviving. The ability to survive was only partially restored by pCU1-isdH $H^{+}(18.7 \pm 2.6 \%)$. In contrast, the spa mutant was significantly impaired, with $36.2 \pm 3.1 \%$ of the inoculum surviving. Survival of the double spa isdH mutant was at the same level as that of the isdH mutant $(7.4 \pm 3.1 \%)$. L. lactis expressing IsdH was also protected $(54.4 \pm 6.4 \%)$ compared with the non-IsdHexpressing control $(15.0 \pm 3.6 \%, P=0.05)$ (Fig. 3b). It was important to show that the ability of the isd $\mathrm{H}$ mutants to grow in plasma was not impaired by the loss of a protein that is required for binding of haptoglobin and haemoglobin and for iron acquisition. Bacteria were incubated in plasma (lacking cells) for $3 \mathrm{~h}$. The IsdH-defective null mutant and the wild-type proliferated and grew to the same extent $(132.5 \pm 3.5 \%$ and $138.7 \pm 5.3 \%$ of the input inoculum, respectively). These experiments demonstrate that $\mathrm{IsdH}$ is very important for the ability of $S$. aureus to survive in human blood. This is most likely because its ability to resist opsonophagocytosis by neutrophils is lost, and even the presence of protein A, itself a known and here demonstrable anti-phagocytic factor (Gemmell et al., 1991; Palmqvist et al., 2002), was unable to compensate.

\section{S. aureus isdH missense mutations}

The failure of pCU1-isd $H^{+}$to restore the ability of the isdH null mutant to survive in human blood prompted the construction of is $d H$ mutants that expressed, from the chromosomal locus, mutant proteins that were defective in ligand binding. Examination of the amino acid sequences of NEAT motifs indicated that residues in the loop between $\beta$-strands $1 \mathrm{~b}$ and 2 are likely to be involved in binding haemoglobin (and $\mathrm{Hp}-\mathrm{Hb}$ ). We made the assumption that the binding site for $\mathrm{Hp}-\mathrm{Hb}$ is likely to be used in binding by ligands involved in immune evasion. The triple amino acid substitution mutation (Y126A/H127E/F128A) was introduced into the is $d H$ gene by allele replacement. A second mutation affecting D206 (D206A) located in the loop between $\beta$-strands 7 and 8 was also generated. Western immunoblotting was performed with cell wall 


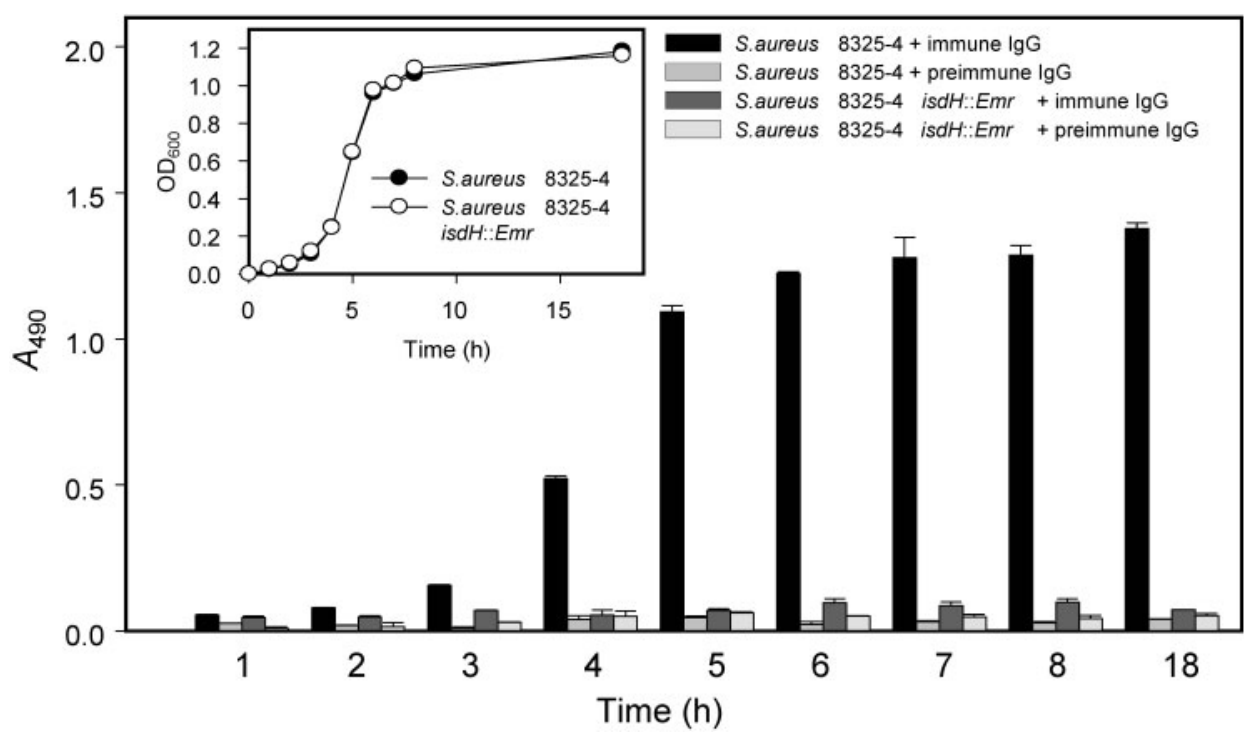

Fig. 2. IsdH is surface-exposed and preferentially expressed in the stationary phase. S. aureus $8325-4$ cells $\left(5 \times 10^{7}\right)$ grown in RPMI 1640 and harvested at different times were immobilized onto microtitre wells, and incubated with a rabbit anti-lsdH41321 antibody followed by HRP-conjugated goat anti-rabbit IgG. S. aureus 8325-4 isdH was included as a control. Duplicate wells were tested for reactivity with a pre-immune rabbit IgG. Inset: growth curves of $S$. aureus $8325-4$ and the isdH mutant.

proteins solubilized by lysostaphin during the creation of stabilized protoplasts. This showed that the mutant IsdH proteins were expressed at the same level as the wild-type protein (Fig. 1c). Control blotting experiments showed that the expression of IsdB was not altered in the mutant strains (Fig. 1d).

To determine the effects of the changes on ligand binding, a recombinant GST fusion comprising the $\mathrm{N}$-terminal IsdH residues 41-321 including the entire NEAT1 motif was expressed and purified along with rIsdH41-321 variants with Y126A/H127E/F128A and D206A substitutions. Solidphase ligand binding assays were performed with immobilized $\mathrm{Hp}-\mathrm{Hb}$ (Fig. 4a) and haemoglobin (not shown). GST-IsdH41-321 bound to immobilized $\mathrm{Hp}-\mathrm{Hb}$ in a dosedependent and saturable manner, with a half-maximum binding concentration of $1.8 \mathrm{nM}$. The Y126A/H127E/ F128A mutant was defective in binding to immobilized $\mathrm{Hp}-\mathrm{Hb}$, whereas the D206A mutant bound with an affinity similar to that of the wild-type. Similar results were obtained when the reciprocal binding assays were performed (GST protein immobilized, $\mathrm{Hp}-\mathrm{Hb}$ in solution; Fig. 4b) with the wild-type and D206A mutants having half-maximum binding concentrations of 1.2 and $2.8 \mathrm{nM}$, respectively. Similar trends were seen with haemoglobin (immobilized haemoglobin, wild-type and D206A $100 \mathrm{nM}$; immobilized GST-IsdH proteins, wild-type $1 \mu \mathrm{M}$ and D206A $2.5 \mu \mathrm{M}$; data not shown).

Blood survival experiments were also performed with the substitution mutants. In each case, the isdH null mutant and both of the substitution mutants were killed more efficiently than the wild-type, for which between 40 and
$50 \%$ of the inoculum survived (Fig. 3a). This further supports the notion that $\mathrm{IsdH}$ is important in determining survival from phagocytosis in whole blood.

\section{Phagocytosis by human neutrophils}

In order to investigate whether expression of IsdH reduces the ability of human neutrophils to engulf $S$. aureus cells, the mutant 8325-4 isdH was compared with the wild-type strain and with 8325-4 defective in the well-characterized anti-phagocytic surface factor protein A (8325-4 spa) in in vitro phagocytosis assays. Bacteria were grown in RPMI 1640 and incubated with purified human neutrophils in the presence of up to $10 \%$ NHS. The isdH mutant was engulfed at a significantly greater rate than wild-type (Fig. $5 \mathrm{a})$. The spa mutant showed a slightly greater increase in phagocytosis, as did the isdH spa double mutant. Also, $L$. lactis carrying pKS80-isdH was phagocytosed at a lower level than the parental strain in $10 \%$ NHS, showing that IsdH can protect when expressed in a surrogate host (Fig. $5 b)$. A second experiment was performed with the IsdH substitution mutants (Fig. 5c). With both 3 and $10 \%$ serum, the difference in uptake between the wild-type and the mutants was statistically significant $(P<0.01)$. These experiments show that expression of IsdH is important for $S$. aureus to avoid opsonophagocytosis.

\section{Virulence in mice}

An earlier study has indicated that IsdH is not an obvious virulence factor in a mouse sepsis model that involved measuring bacterial cells growing in the kidney and spleen 

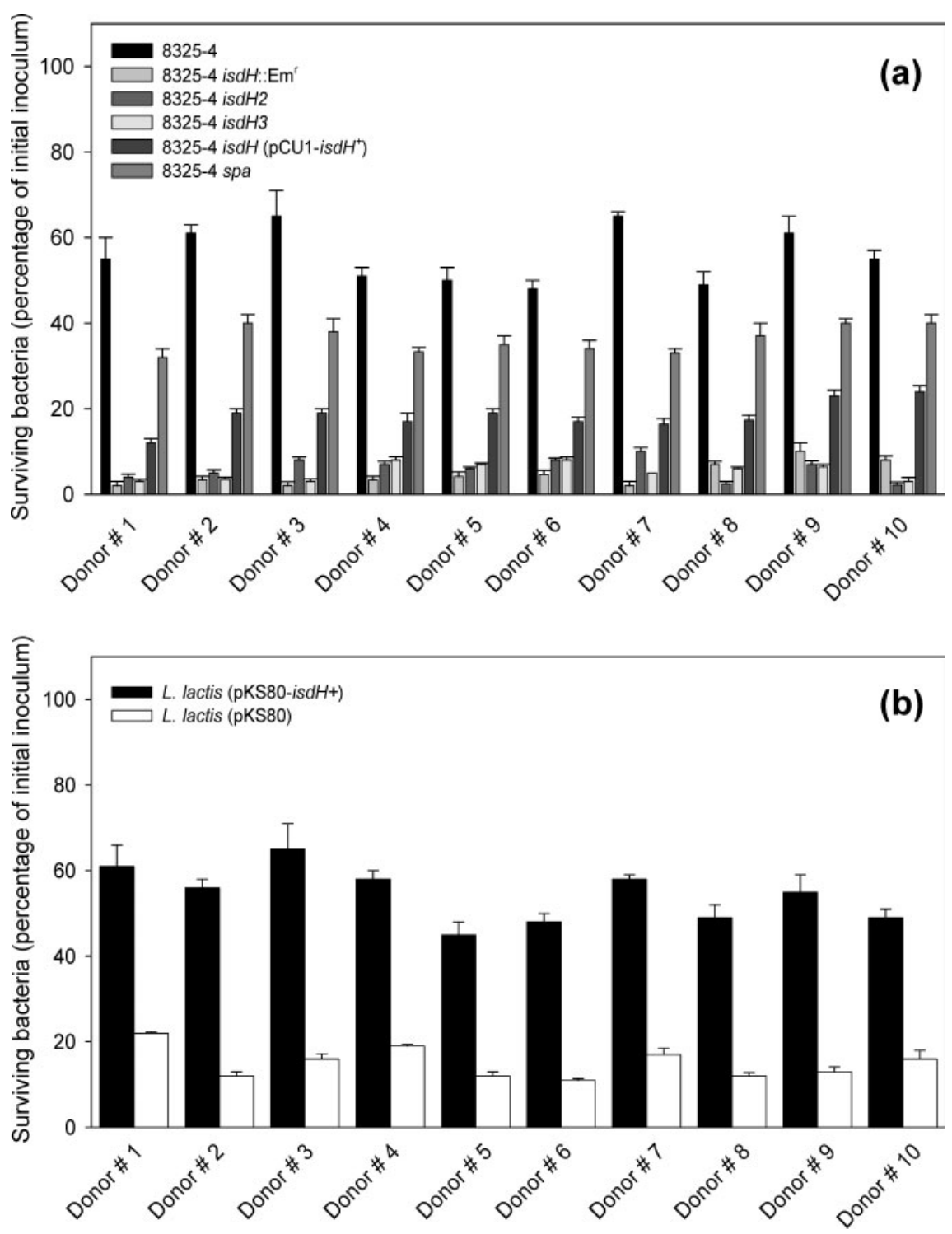

Fig. 3. Expression of IsdH inhibits killing of $S$. aureus in human blood. (a) S. aureus 8325-4, 8325-4 isdH, 8325-4 spa and 8325-4 isdH (pCU1-isd $H^{+}$) mutants grown in RPMl 1640 were tested for their ability to survive $3 \mathrm{~h}$ incubation in human blood. (b) $\mathrm{L}$. lactis with pKS80 or pKS80-isd $H^{+}$. Surviving bacteria were detected by viable counting. Data are presented as the mean percentage \pm SD of surviving c.f.u.

4 days after intravenous inoculation (Torres et al., 2006). Given the data described above indicating that IsdH is important for resisting opsonophagocytosis, we investigated a possible role for IsdH in S. aureus virulence by measuring the time to death of mice that were injected intravenously with sufficient cells to induce mortality. The experiment was performed twice with very similar results, and the pooled data are presented. It is evident from the data shown in Fig. 6 that mice infected with the isdH mutant were killed more slowly than those infected with the wild-type strain. There were significant differences in survival between the groups $(P=0.044)$. The survival was thus prolonged in mice infected with bacteria that lacked isdH.

\section{IsdH promotes cleavage of C3b}

S. aureus cells grown in iron-replete broth absorb complement regulatory factor I from serum in an active form and use it to degrade C3b opsonins deposited on the cell surface (Cunnion et al., 2004). Since IsdH appears to have a potent anti-phagocytic effect, we monitored the degradation of C3b that was fixed onto the cell surface by the combined alternative, classical and lectin pathways 

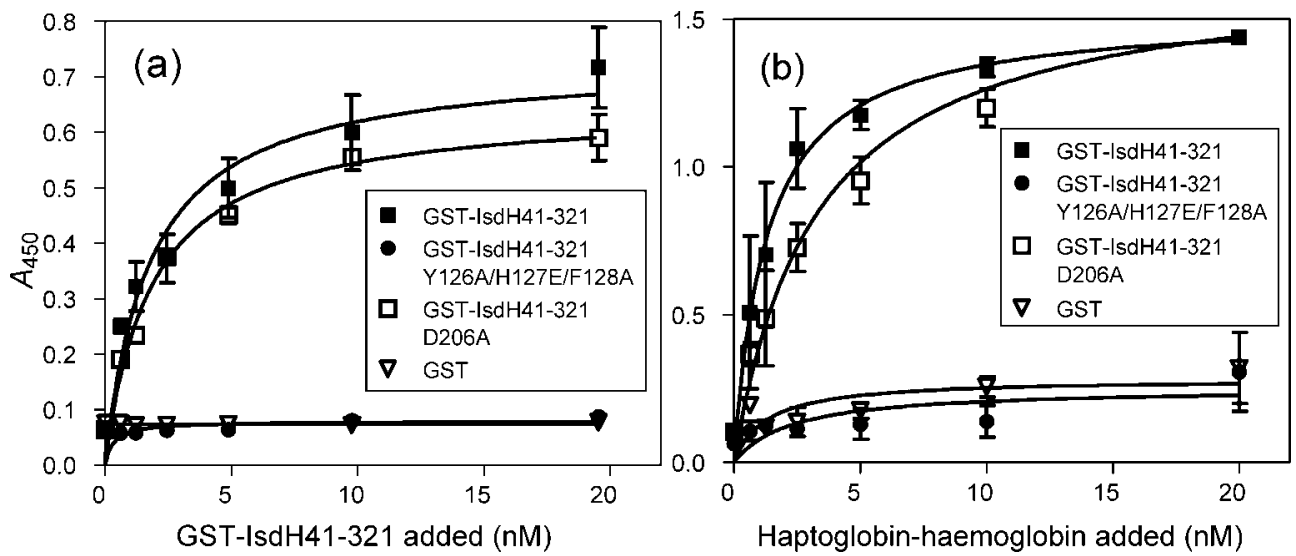

Fig. 4. IsdH binding to $\mathrm{Hp}-\mathrm{Hb}$. Plates (96-well) were coated with (a) $\mathrm{Hp}-\mathrm{Hb}$ or (b) GST-IsdH41-321 proteins, and incubated with various concentrations of (a) GST-IsdH41-321 or (b) $\mathrm{Hp}-\mathrm{Hb}$. Bound proteins were detected with (a) HRP-conjugated goat anti-GST antibody or (b) rabbit anti-haemoglobin antibody followed by HRP-conjugated goat anti-rabbit lgG.

during incubation in serum or by the alternative pathway alone. Preliminary experiments indicated that $\mathrm{C} 3 \mathrm{~b}$ was almost completely degraded to iC3b on the wild-type cell but that significant amounts remained on the surface of the
isdH mutants after $30 \mathrm{~min}$ (data not shown). In order to analyse whether IsdH mediates $\mathrm{C} 3 \mathrm{~b}$ conversion to $\mathrm{C} 3 \mathrm{~d}$ during serum incubation, bacterial cells were removed after 30 or 60 min and incubated with anti-C3c or anti-C3d
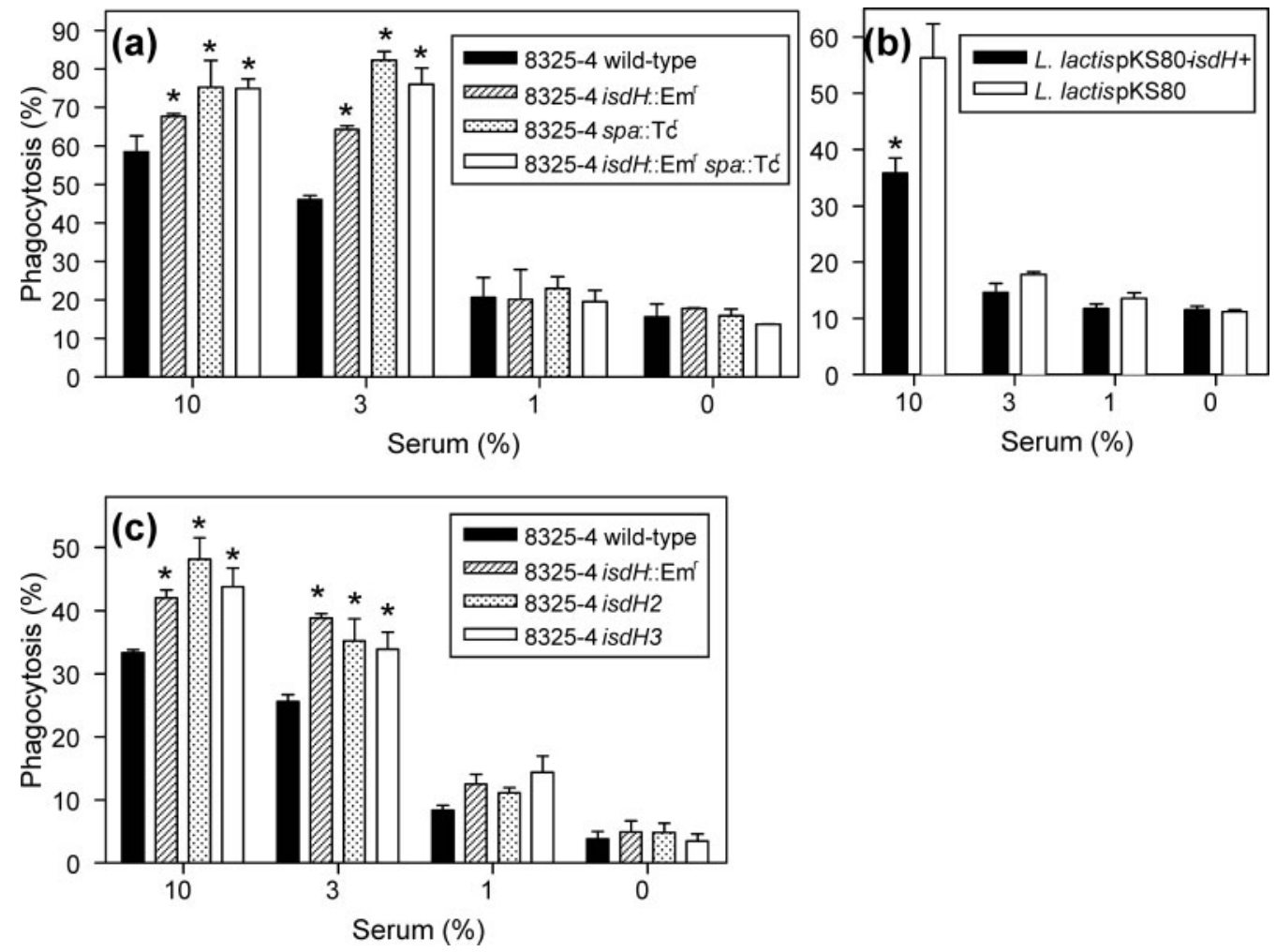

Fig. 5. Phagocytosis. (a, c) S. aureus 8325-4, 8325-5 isdH, 8325-4 spa and 8325-4 isdH spa cells grown in RPMl 1640 and (b) L. lactis (pKS80) and L. lactis (pKS80-isd $H^{+}$) mutant cells were labelled with FITC, adjusted to $5 \times 10^{7}$, opsonized with 1,3 or $10 \%$ pooled human sera, and incubated with human PMNL from different donors. After stopping the reaction, the percentage of PMNL bearing fluorescent bacteria was measured by flow cytometry. Tests were performed in triplicate using blood from three different donors. (a) ${ }^{*} P<0.01$ compared with $8325-4$ wild-type; (b) ${ }^{*} P<0.01$ compared with $L$. lactis (pKS80); (c) ${ }^{\star} P<0.01$ compared with 8325-4 wild-type. 


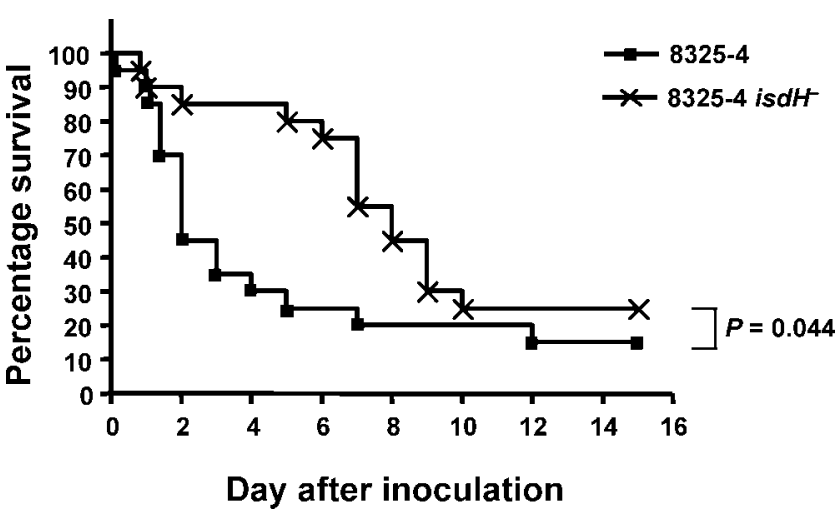

Fig. 6. Experimental sepsis. Survival of mice after intravenous inoculation with $9.7-10.2 \times 10^{8}$ c.f.u. $8325-4$ wild-type or $10.2-$ $10.4 \times 10^{8}$ c.f.u. $8325-4$ isdH. $n=20$ per group at the start. Statistical analysis was performed with the logrank test. Mice that had not died at the time of analysis were censored.

antibodies. The former will recognize both $\mathrm{C} 3 \mathrm{~b}$ and $\mathrm{iC} 3 \mathrm{~b}$ but not C3d, whereas the latter will bind to all three forms of $\mathrm{C} 3$ derivative. Antibody binding was measured by flow cytometry. There was a significant progressive reduction in fluorescence intensity for anti-C3c antibodies with the wild-type but not the isd $\mathrm{H}$ mutants (Fig. 7a), while the fluorescence due to anti-C3d antibody binding was the same in wild-type and isdH mutants (Fig. 7b). This suggests that IsdH mediates the conversion of $\mathrm{C} 3 \mathrm{~b}$ to $\mathrm{iC} 3 \mathrm{~b}$ and C3d, which could explain the anti-phagocytic effect.

\section{DISCUSSION}

The research described in this paper reveals that surface protein IsdH seems to have an important role in determining the ability of $S$. aureus to survive during infection. We have shown that the presence of IsdH on the bacterial cell surface reduces the uptake of bacteria by human neutrophils in the presence of serum opsonins and promotes the survival of bacteria in human blood. Furthermore, in a murine model of bacteraemia and sepsis, the mice infected with $\mathrm{IsdH}^{-}$bacteria survived for several days longer than mice infected with $\mathrm{IsdH}^{+}$bacteria. Is $\mathrm{dH}^{+}$bacteria survived for longer in the mouse, which led to septic death more rapidly than if the infecting bacteria did not express IsdH. These data seem to contradict an earlier report (Torres et al., 2006) that $\mathrm{IsdH}$ is not a virulence factor in a mouse infection model. Our experiment involved a higher inoculum and measured acute sepsis, while the earlier study used a smaller inoculum and measured the ability of bacteria to colonize and survive in abscesses in internal organs. In our study we spotted a delayed time to death in the IsdH-defective mutantinfected animals. This is a measure of severity of disease. Ultimately, the overall lethality of the mutant was the same as that of the wild-type. Clinically, it would be very valuable to be able to delay the septic process for any period of time, to give more time for therapeutic intervention. If IsdH could be targeted during an ongoing infection a delay in the septic process might result.

S. aureus surface proteins are known to inhibit opsonophagocytosis and killing via different mechanisms. (i) The recognition of complement and immunoglobulin by neutrophil receptors is blocked by the binding of protein A to IgG (Gemmell et al., 1991; Uhlen et al., 1984) and microbial surface components recognizing adhesive matrix molecules (MSCRAMMs) to fibrinogen (Higgins et al., 2006). The efficiency of complement fixation via the classical pathway is impaired by protein A binding to the IgG Fc region. (ii) The degradation of $\mathrm{C} 3 \mathrm{~b}$ to $\mathrm{iC} 3 \mathrm{~b}$ is enhanced by capture of complement factor I (Cunnion et al., 2004). (iii) Resistance is conferred to antimicrobial substances within the neutrophil phagosome. The data presented in this paper support the second mechanism, and future work
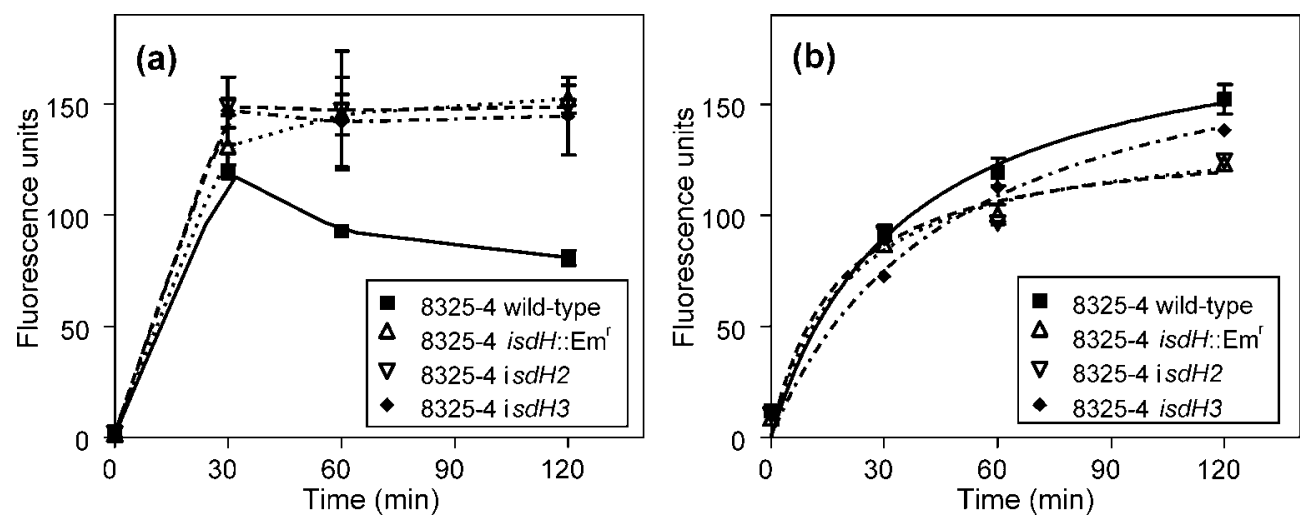

Fig. 7. Flow cytometry to detect $\mathrm{C} 3$ degradation products. S. aureus Is $\mathrm{dH}^{+}$and $I \mathrm{IdH}^{-}$were grown in RPMI 1640 and incubated with pooled human serum in MgEGTA at $37^{\circ} \mathrm{C}$. After halting complement activation, cells were probed with rabbit anti-C3c (a) or anti-C3d (b) antibodies and FITC-labelled anti-rabbit IgG. The mean fluorescence of 10000 cells was measured by flow cytometry. 
will be directed towards understanding the mechanism involved.

When trying to complement the is $d H$ null mutant with the wild-type gene cloned on a multicopy plasmid we observed that lethality in the blood survival experiment was not restored to wild-type levels. In order to overcome the difficulty in complementation and to confirm the importance of IsdH in resistance to opsonophagocytosis, amino acid substitution mutations were created in the chromosomal is $d H$ gene. It was predicted that residues Y126, H127 and F128, which are located on a surface-exposed loop spanning $\beta$-strands $1 \mathrm{~b}$ and 2 , are important in binding to haemoglobin and $\mathrm{Hp}-\mathrm{Hb}$ (Pilpa et al., 2006). The N-terminal domain of IsdH containing NEAT1 bound strongly to $\mathrm{Hp}-\mathrm{Hb}$ and to haemoglobin in in vitro solidphase assays. Mutants with substitutions at Y126A/H127E/ F128A, but not in D206 located in a loop between $\beta$ strands 7 and 8 and also exposed on the same face of the protein as loop 1b-2, were defective in binding these ligands. We made the assumption that residues involved in binding to haptoglobin and haemoglobin might also be important in resistance to opsonophagocytosis. Amino acid substitution mutants expressed by the mutated chromosomal is $d H$ gene showed the same defect as the null mutant in survival in blood and phagocytosis in vitro by human neutrophils. This confirms the importance of IsdH in combating opsonophagocytosis. The failure of complementation hints that expression of the Isd proteins may be more complicated than first expected, perhaps requiring the assembly of a protein complex in an ordered way on the cell surface. The observation that both substitution mutants were defective in survival but that only the Y126A/H127E/ F128A mutant recombinant protein was defective in binding $\mathrm{Hp}-\mathrm{Hb}$ suggests that the ligands involved in immune evasion bind to both loops $1 \mathrm{~b}-2$ and $7-8$.

Using isogenic mutants of IsdH we have shown that this surface protein is anti-phagocytic. The presence of IsdH enhances conversion of C3b to iC $3 b$ and C3d. Since both $\mathrm{C} 3 \mathrm{~b}$ and $\mathrm{iC} 3 \mathrm{~b}$ can serve as ligands for complement receptors on phagocytosing cells, we think that IsdH blocks phagocytosis by promoting rapid conversion of $\mathrm{C} 3 \mathrm{~b}$ to $\mathrm{C} 3 \mathrm{~d}$. Since we observed no differences in initial C3b deposition we believe that the inactivation of $\mathrm{C} 3 \mathrm{~b}$ by IsdH does not affect $\mathrm{C} 3$ convertase formation but is mainly important for blocking phagocytic processes. Possibly, IsdH is also involved in blocking C5a formation, since C3b plays a crucial role in formation of $\mathrm{C} 5$ convertases. We could not observe enhanced $\mathrm{C} 3 \mathrm{~b}$ degradation when all pathways were active (resulting in massive deposition of $\mathrm{C} 3 \mathrm{~b}$ ), indicating the dose-dependent action of IsdH. It is also possible that a masking effect by the IsdH protein binding to $\mathrm{Hp}-\mathrm{Hb}$ present in serum contributes to impaired phagocytosis.

The blood survival experiments were performed with samples that contained no detectable anti-IsdH antibodies, whereas the in vitro phagocytosis experiment was performed with pooled human sera that contained low levels of
anti-IsdH antibodies. However, this did not seem to affect the outcome of the experiments, because both substitution mutants that expressed a form of IsdH on the cell surface and the null mutant lacking any IsdH were similarly defective.

At first sight it is perhaps difficult to reconcile the large differences in whole blood killing with the modest changes in in vitro phagocytosis. However, the assays are quite distinct in many respects. In the whole blood assay, the incubation time was $3 \mathrm{~h}$ rather than the $3-10$ min used in in vitro phagocyosis. The phagocytosis experiment measures uptake alone, whereas in whole blood both uptake and killing are measured. Furthermore, in the in vitro phagocytosis assay, low concentrations of serum are used and neutrophils are purified and are often partially degranulated, whereas in whole blood, the serum concentration is normal and neutrophils have not been disturbed. The possibility that IsdH has a role in promoting survival within phagocytes will be investigated in the future.

Future research will provide more insight into the C3bmodulating activity of IsdH. The observed enhanced conversion of surface-bound $\mathrm{C} 3 \mathrm{~b}$ can be explained in several ways: (i) IsdH could act as a factor I-mimicking protease; (ii) IsdH could capture human cofactor factor $\mathrm{H}$; or (iii) IsdH could directly trap factor I to the bacterial surface. Clumping factor A of $S$. aureus has recently been identified as a direct ligand for factor I (Cunnion et al., 2004). In our study, ClfA is unlikely to have played a part because we employed strain $8325-4$, which expresses very low levels of that protein due to a defect in expression of sigma factor $B$ required for transcription of the clfA gene (Bischoff et al., 2004). The previous work would not have detected a role for IsdH because bacteria were grown in iron-replete media and not under the iron-restricted conditions needed to induce expression of Isd proteins. Our future work will be directed towards unravelling the mechanism of enhanced C3b degradation.

\section{ACKNOWLEDGEMENTS}

T.J.F. wishes to thank Science Foundation Ireland for a Programme Investigator Grant. P.S. acknowledges Fondazione CARIPLO (2003.1640/10.8485) and FAR (Fondo d'Ateneo per la Ricerca, University of Pavia, Italy). L.V. thanks the Italian Ministero dell'Istruzione, dell'Università e della Ricerca, IDEE PROGETTUALI (Grandi Programmi Strategici, D.M. n ${ }^{\circ}$ 24695, Prot. RBIPO6FH7 J) and Dr R. Poma (Policlinico San Matteo, Pavia, Italy) for supplying fresh human blood samples. E. J. and A.T. thank Göteborg Medical Society, Göteborg Rheumatism Association, King Gustaf V's 80 Years Foundation, LUA/ALF, Swedish Research Council, Swedish Rheumatism Association, The Sigurd and Elsa Golje Memorial Foundation and The Family Thöléns and Kristlers Foundation. S.H.M.R. is supported by the Netherlands Organization for Scientific Research (NWO)-VENI (916-76-037).

\section{REFERENCES}

Andrade, M. A., Ciccarelli, F. D., Perez-Iratxeta, C. \& Bork, P. (2002). NEAT: a domain duplicated in genes near the components of a 
putative $\mathrm{Fe}^{3+}$ siderophore transporter from Gram-positive pathogenic bacteria. Genome Biol 3, RESEARCH0047.

Augustin, J., Rosenstein, R., Wieland, B., Schneider, U., Schnell, N., Engelke, G., Entian, K. D. \& Gotz, F. (1992). Genetic analysis of epidermin biosynthetic genes and epidermin-negative mutants of Staphylococcus epidermidis. Eur J Biochem 204, 1149-1154.

Bestebroer, J., Poppelier, M. J., Ulfman, L. H., Lenting, P. J., Denis, C. V., van Kessel, K. P., van Strijp, J. A. \& de Haas, C. J. (2007). Staphylococcal superantigen-like 5 binds PSGL-1 and inhibits Pselectin-mediated neutrophil rolling. Blood 109, 2936-2943.

Bischoff, M., Dunman, P., Kormanec, J., Macapagal, D., Murphy, E., Mounts, W., Berger-Bachi, B. \& Projan, S. (2004). Microarray-based analysis of the Staphylococcus aureus $\sigma^{\mathrm{B}}$ regulon. I Bacteriol 186, 4085-4099.

Chavakis, T., Hussain, M., Kanse, S. M., Peters, G., Bretzel, R. G., Flock, J. I., Herrmann, M. \& Preissner, K. T. (2002). Staphylococcus aureus extracellular adherence protein serves as anti-inflammatory factor by inhibiting the recruitment of host leukocytes. Nat Med 8, 687-693.

Clarke, S. R. \& Foster, S. J. (2008). IsdA protects Staphylococcus aureus against the bactericidal protease activity of apolactoferrin. Infect Immun 76, 1518-1526.

Clarke, S. R., Wiltshire, M. D. \& Foster, S. J. (2004). IsdA of Staphylococcus aureus is a broad spectrum, iron-regulated adhesin. Mol Microbiol 51, 1509-1519.

Clarke, S. R., Brummell, K. J., Horsburgh, M. J., McDowell, P. W., Mohamad, S. A., Stapleton, M. R., Acevedo, J., Read, R. C., Day, N. P \& other authors (2006). Identification of in vivo-expressed antigens of Staphylococcus aureus and their use in vaccinations for protection against nasal carriage. J Infect Dis 193, 1098-1108.

Clarke, S. R., Mohamed, R., Bian, L., Routh, A. F., Kokai-Kun, J. F., Mond, J. J., Tarkowski, A. \& Foster, S. J. (2007). The Staphylococcus aureus surface protein IsdA mediates resistance to innate defenses of human skin. Cell Host Microbe 1, 199-212.

Cunnion, K. M., Hair, P. S. \& Buescher, E. S. (2004). Cleavage of complement $\mathrm{C} 3 \mathrm{~b}$ to $\mathrm{iC} 3 \mathrm{~b}$ on the surface of Staphylococcus aureus is mediated by serum complement factor I. Infect Immun 72, 2858-2863.

de Haas, C. J., Veldkamp, K. E., Peschel, A., Weerkamp, F., Van Wamel, W. J., Heezius, E. C., Poppelier, M. J., Van Kessel, K. P. \& van Strijp, J. A. (2004). Chemotaxis inhibitory protein of Staphylococcus aureus, a bacterial antiinflammatory agent. J Exp Med 199, 687-695.

Dombek, P. E., Cue, D., Sedgewick, J., Lam, H., Ruschkowski, S., Finlay, B. B. \& Cleary, P. P. (1999). High-frequency intracellular invasion of epithelial cells by serotype M1 group A streptococci: M1 protein-mediated invasion and cytoskeletal rearrangements. Mol Microbiol 31, 859-870.

Fitzgerald, J. R., Loughman, A., Keane, F., Brennan, M., Knobel, M., Higgins, J., Visai, L., Speziale, P., Cox, D. \& Foster, T. J. (2006). Fibronectin-binding proteins of Staphylococcus aureus mediate activation of human platelets via fibrinogen and fibronectin bridges to integrin GPIIb/IIIa and IgG binding to the Fc $\gamma$ RIIa receptor. $\mathrm{Mol}$ Microbiol 59, 212-230.

Foster, T. J. (1998). Molecular genetic analysis of staphylococcal virulence. In Methods in Microbiology, vol. 27, pp. 433-454. Edited by J. K. P. H. Williams \& G. Salmond. Oxford, UK: Elsevier.

Foster, T. J. (2005). Immune evasion by staphylococci. Nat Rev Microbiol 3, 948-958.

Gemmell, C., Tree, R., Patel, A., O'Reilly, M. \& Foster, T. J. (1991). Susceptibility to opsonophagocytosis of protein A, $\alpha$-haemolysin and $\beta$-toxin deficient mutants of Staphylococcus aureus isolated by allelereplacement. Zentralbl Bakteriol(Suppl.), 273-277.
Hair, P. S., Ward, M. D., Semmes, O. J., Foster, T. J. \& Cunnion, K. M. (2008). Staphylococcus aureus clumping factor A binds to complement regulator factor I and increases cleavage of C3b. J Infect Dis 198, 125-133.

Hartford, O., O’Brien, L., Schofield, K., Wells, J. \& Foster, T. J. (2001). The Fbe (SdrG) protein of Staphylococcus epidermidis HB promotes bacterial adherence to fibrinogen. Microbiology 147, 2545-2552.

Higgins, J., Loughman, A., van Kessel, K. P., van Strijp, J. A. \& Foster, T. J. (2006). Clumping factor A of Staphylococcus aureus inhibits phagocytosis by human polymorphonuclear leucocytes. FEMS Microbiol Lett 258, 290-296.

Jongerius, I., Kohl, J., Pandey, M. K., Ruyken, M., van Kessel, K. P., van Strijp, J. A. \& Rooijakkers, S. H. (2007). Staphylococcal complement evasion by various convertase-blocking molecules. J Exp Med 204, 2461-2471.

Jonsson, K., McDevitt, D., McGavin, M. H., Patti, J. M. \& Hook, M. (1995). Staphylococcus aureus expresses a major histocompatibility complex class II analog. J Biol Chem 270, 21457-21460.

Kemp, E. H., Sammons, R. L., Moir, A., Sun, D. \& Setlow, P. (1991). Analysis of transcriptional control of the gerD spore germination gene of Bacillus subtilis 168. J Bacteriol 173, 4646-4652.

Kreiswirth, B. N., Lofdahl, S., Betley, M. J., O'Reilly, M., Schlievert, P. M., Bergdoll, M. S. \& Novick, R. P. (1983). The toxic shock syndrome exotoxin structural gene is not detectably transmitted by a prophage. Nature 305, 709-712.

Lowy, F. D. (1998). Staphylococcus aureus infections. N Engl J Med 339, 520-532.

Mazmanian, S. K., Skaar, E. P., Gaspar, A. H., Humayun, M., Gornicki, P., Jelenska, J., Joachmiak, A., Missiakas, D. M. \& Schneewind, O. (2003). Passage of heme-iron across the envelope of Staphylococcus aureus. Science 299, 906-909.

Molkanen, T., Tyynela, J., Helin, J., Kalkkinen, N. \& Kuusela, P. (2002). Enhanced activation of bound plasminogen on Staphylococcus aureus by staphylokinase. FEBS Lett 517, 72-78.

Novick, R. (1967). Properties of a cryptic high-frequency transducing phage in Staphylococcus aureus. Virology 33, 155-166.

O'Seaghdha, M., van Schooten, C. J., Kerrigan, S. W., Emsley, J., Silverman, G. J., Cox, D., Lenting, P. J. \& Foster, T. J. (2006). Staphylococcus aureus protein A binding to von Willebrand factor A1 domain is mediated by conserved IgG binding regions. FEBS J 273, 4831-4841.

Palmqvist, N., Foster, T., Tarkowski, A. \& Josefsson, E. (2002). Protein A is a virulence factor in Staphylococcus aureus arthritis and septic death. Microb Pathog 33, 239-249.

Peacock, S. J., de Silva, I. \& Lowy, F. D. (2001). What determines nasal carriage of Staphylococcus aureus? Trends Microbiol 9, 605-610.

Pilpa, R. M., Fadeev, E. A., Villareal, V. A., Wong, M. L., Phillips, M. \& Clubb, R. T. (2006). Solution structure of the NEAT (NEAr Transporter) domain from IsdH/HarA: the human hemoglobin receptor in Staphylococcus aureus. J Mol Biol 360, 435-447.

Prat, C., Bestebroer, J., de Haas, C. J., van Strijp, J. A. \& van Kessel, K. P. (2006). A new staphylococcal anti-inflammatory protein that antagonizes the formyl peptide receptor-like 1. J Immunol 177, 80178026.

Roche, F. M., Massey, R., Peacock, S. J., Day, N. P., Visai, L., Speziale, P., Lam, A., Pallen, M. \& Foster, T. J. (2003). Characterization of novel LPXTG-containing proteins of Staphylococcus aureus identified from genome sequences. Microbiology 149, 643-654.

Rooijakkers, S. H., Ruyken, M., Roos, A., Daha, M. R., Presanis, J. S., Sim, R. B., van Wamel, W. J., van Kessel, K. P. \& van Strijp, J. A. (2005a). Immune evasion by a staphylococcal complement inhibitor that acts on C3 convertases. Nat Immunol 6, 920-927. 
Rooijakkers, S. H., van Wamel, W. J., Ruyken, M., van Kessel, K. P. \& van Strijp, J. A. (2005b). Anti-opsonic properties of staphylokinase. Microbes Infect 7, 476-484.

Skaar, E. P. \& Schneewind, O. (2004). Iron-regulated surface determinants (Isd) of Staphylococcus aureus: stealing iron from heme. Microbes Infect 6, 390-397.

Thakker, M., Park, J. S., Carey, V. \& Lee, J. C. (1998). Staphylococcus aureus serotype 5 capsular polysaccharide is antiphagocytic and enhances bacterial virulence in a murine bacteremia model. Infect Immun 66, 5183-5189.

Torres, V. J., Pishchany, G., Humayun, M., Schneewind, O. \& Skaar, E. P. (2006). Staphylococcus aureus IsdB is a hemoglobin receptor required for heme iron utilization. J Bacteriol 188, 8421-8429.

Uhlen, M., Guss, B., Nilsson, B., Gatenbeck, S., Philipson, L. \& Lindberg, M. (1984). Complete sequence of the staphylococcal gene encoding protein A. A gene evolved through multiple duplications. J Biol Chem 259, 1695-1702.

Vuong, C., Voyich, J. M., Fischer, E. R., Braughton, K. R., Whitney, A. R., DeLeo, F. R. \& Otto, M. (2004). Polysaccharide intercellular adhesin (PIA) protects Staphylococcus epidermidis against major components of the human innate immune system. Cell Microbiol 6, 269-275.

Wertheim, H. F., Vos, M. C., Ott, A., van Belkum, A., Voss, A., Kluytmans, J. A., van Keulen, P. H., Vandenbroucke-Grauls, C. M., Meester, M. H. \& Verbrugh, H. A. (2004). Risk and outcome of nosocomial Staphylococcus aureus bacteraemia in nasal carriers versus non-carriers. Lancet 364, 703-705.

Edited by: S. J. Foster 